\title{
Contextualizing local landscape initiatives in global change: a scenario study for the high forest zone, Ghana
}

\author{
Sarah Wolff ${ }^{1} \cdot$ Johan $_{\text {Meijer }}{ }^{2}$ Catharina J. E. Schulp ${ }^{1}$ (I) $\cdot$ Peter H. Verburg ${ }^{1,3}$ \\ Received: 12 December 2019 / Accepted: 24 August 2020 / Published online: 22 September 2020 \\ (C) The Author(s) 2020
}

\begin{abstract}
Integrated landscape management (ILM) has received increased interest to reconcile multiple conflicting demands on a landscape scale. ILM aims at addressing major interconnected global challenges, such as poverty, food security, deforestation, and climate change. A principal element of ILM is the consideration of multiple scales, harmonizing local-level needs and ambitions with those that derive from outside the landscape. ILM initiatives are most often initiated by local actors focusing on local priorities, thereby insufficiently realizing that the landscape is embedded in a wider macroeconomic and societal context. We contextualize a landscape initiative located in the high forest zone of southern Ghana, focusing on global socioeconomic and political developments that are expected to have an influence on the region. We built two "sustainability" scenarios for the period between 2015 and 2030, reflecting the demands and ambitions of local stakeholders (bottom-up) and of global environmental policy (topdown) for the region. We find that global climate and cocoa production priorities could induce synergies between food production, biodiversity conservation, and climate change mitigation at the scale of the case study region but could come at the cost of mixed forest systems that play an important role in livelihoods on the landscape scale. Land change scenarios can play a critical role in assessing and visualizing such interactions and provide a platform for discussion and negotiation on how to integrate different objectives in the design of landscape initiatives.
\end{abstract}

Keywords Land use competition · West Africa · Scenarios · Cross-scale interactions · Integrated landscape initiatives · Land systems

\section{Introduction}

Land use change (LUC) is driven by demands that operate at multiple spatial scales. In an increasingly interconnected world, decisions on one spatial scale can have effects on other spatial scales (Meyfroidt et al. 2013), leading to feedbacks on land use decisions and trade-offs for the well-being of different societal groups. Understanding the interlinkages between local and global processes and the effects of such interlinkages is thus important. Globally, the growing demand for food,

Communicated by Chinwe Ifejika Speranza

Electronic supplementary material The online version of this article (https://doi.org/10.1007/s10113-020-01701-x) contains supplementary material, which is available to authorized users.

Catharina J. E. Schulp

nynke.schulp@vu.nl

Sarah Wolff

sarah_wolff@live.de

Johan Meijer

johan.meijer@pbl.nl

Peter H. Verburg

peter.verburg@vu.nl
1 Institute for Environmental Studies (IVM), Vrije Universiteit Amsterdam, De Boelelaan 1111, Amsterdam 1081 HV, The Netherlands

2 PBL Netherlands Environmental Assessment Agency, Bezuidenhoutseweg 30, 2594 AV The Hague, The Netherlands

3 Federal Institute for Forest, Snow and Landscape Research (WSL), Zuercherstrasse 111, 8903 Birmensdorf, Switzerland 
climate change mitigation, and biodiversity conservation, arising from population increase and lifestyle changes, pose increasing pressures on land use (Lambin and Meyfroidt 2011; Creutzig et al. 2019). Many desired ecosystem services (ES) cannot sufficiently be found in a country's own territories. Particularly, climate change mitigation, biodiversity conservation, food, and bioenergy production are becoming increasingly telecoupled (Friis et al. 2015). While the demand for these ES is spread all over the globe (Serna-Chavez et al. 2014; Eitelberg et al. 2016; Fuchs et al. 2017), the supply is concentrated in regions that host sufficient ES to meet these global demands. As a consequence, those regions experience an expansion of agriculture, as well as large-scale land acquisitions by foreign governments, companies, or individuals (Nolte et al. 2016).

Integrated landscape management (ILM) has emerged as a natural resource use strategy to respond to growing competition for natural resources. It aims to achieve multiple objectives, by managing demands from different sectors and stakeholders in a way that is more sustainable, inclusive, and effective at a local scale (Reed et al. 2017). The main rationale of ILM is to address the "dynamics, linkages, synergies, and trade-offs among multiple objectives, land units, and stakeholder interests, as well as to manage and overcome conflicts" (Scherr et al. 2014). ILM focuses on finding local solutions to global challenges that converge on the landscape scale. An example is the need to find landscape-scale solutions to combine growing agricultural demand with biodiversity conservation (Sayer et al. 2013; Wu 2013). Several programs and environmental policies that aim to enhance and conserve ES, such as the Convention on Biological Diversity "Aichi targets" (CBD 2011), the UN Convention to Combat Desertification "Land Degradation Neutral" (UNCCD 2012), and the UN Sustainable Development Goals (SDGs) (i.e., target 2, 12, 15) (UN 2015), align with the elements of ILM: "allocating and managing land to achieve social, economic and environmental objectives in areas where productive land uses compete with environmental and biodiversity goals" (Sayer et al. 2013). ILM methods and practices have been applied in 436 programs, among others in Africa, Latin America, the Caribbean, South and Southeast Asia, and Europe (Milder et al. 2014; Zanzanaini et al. 2017).

As a bottom-up process, ILM initiatives are often initiated at the local level, reflecting local stakeholders' interest, yet they can be more sustainable if the landscape ambitions are embedded in the context of global, external developments. This includes the influence of global socioeconomic developments and environmental changes that may influence future local landscape ambitions (Heck et al. 2018). Accounting for the wider context of the landscape can help to identify potential conflicts resulting from the needs of different levels (Seppelt et al. 2013). For example, achieving climate change mitigation targets at a national or global level can cause trade- offs with local desired ambitions, such as food security, inducing negative impacts on local livelihoods. To achieve ILM that is sustainable across scales, a better understanding of how external drivers could affect ILM initiatives is needed to reduce risks and to allow for adapting the landscape to future developments (Fedele et al. 2018).

Integrated analysis can help determine hotspots of landscape changes, propose how a balance among different objectives can be achieved, and provide guidance for short- and long-term sustainable land use decisions (Thaxton et al. 2017; Verhagen et al. 2018). LUC scenarios that provide spatially explicit visualization of such changes can be used to identify trade-offs and synergies among objectives in the landscape.

So far, drivers of land use or land system changes have been addressed from either a macroeconomic or local perspective (Verburg et al. 2008). Larger-scale studies that take a macroeconomic perspective have used outputs from macroeconomic and integrated assessment models (IAMs) (e.g., Eitelberg et al. 2016), or optimization models, e.g., to harmonize land use goals related to the SDGs across local, national, and global scales (Heck et al. 2018). Local perspectives have captured cultural and behavioral motives of land use decisionmaking using agent-based modeling (Zagaria et al. 2017). Fewer studies have considered drivers and pressures of LUC that emerge from multiple spatial scales or addressed the potential conflict between them (Gollnow et al. 2018).

In this study, we use the high forest zone (HFZ), located in southern Ghana, as a case study region where multiple interests convene at the landscape scale. We contextualize the region in global socioeconomic development and environmental policy scenarios that could influence the region in the future through expected effects on land use. The aims of this study were (i) to compare global and regional landscape demands and sustainability ambitions for the HFZ and to explore how these could result in different land use futures and (ii) to analyze and compare the resulting land system architectures in terms of their contribution to food production, forest biodiversity conservation, climate change mitigation, and sustainable urbanization.

To do so, we model land system changes in the HFZ between 2015 and 2030 that could result from regional and global landscape demand on this region, accounting for expected changes in socioeconomic developments, associated demand changes, and environmental policy ambitions. We compare an "integrated landscape management" scenario with a "global sustainability" scenario that follow similar sustainability aspirations, but from a local and global scale perspective. As such, we investigate land system change from a bottom-up and top-down perspective. We evaluate the impacts of each scenario on land system architecture and discuss the usefulness of land change scenarios to explore synergies and trade-offs in aligning local and global interests in the landscape. 


\section{Case study region}

The HFZ is located in southern Ghana in the West African region and covers an area of $70,053 \mathrm{~km}^{2}$ (Fig. 1). The HFZ occupies $30 \%$ of the country's land area, but is home to $75 \%$ of Ghana's population, as the region includes the two largest urban agglomerations in Ghana: Accra and Kumasi. The region supplies many ES found in remaining intact forest landscapes, biodiversity hotspots, and climatically suitable areas to grow highquality cash crops, such as cocoa, shea, and coffee.

However, the region experienced drastic rates of deforestation and forest degradation due to agriculture expansion, unsustainable logging, population pressures, and mineral exploitation (for gold and bauxite) (Appiah et al. 2009; Forestry Commission 2010). Over $60 \%$ of the forest area has been lost between 1950 and 2000, with an annual deforestation rate of $3 \%$ (National REDD+ Secretariat 2017). While deforestation in the HFZ is a minor source of $\mathrm{CO}_{2}$ emissions globally, it has had significant effects on the local climate, reflected in increasing temperatures and a decrease in rainfall (Amisah et al. 2009; Boon and Ahenkan 2012). Climate changes are posing risks to the region's cocoa production, threatening the global cocoa supply, as Ghana produces around 25\% of the global cocoa supply. Cocoa production is concentrated in the HFZ region (UN-REDD 2018) and is essential to Ghana's economy. On a local scale, cocoa is of key importance for smallholder livelihoods, contributing to
$70-100 \%$ of annual household income (Okoffo et al. 2016). Natural forests outside the cocoa landscapes are sources of nonwood forest products (NWFP), such as medicine, water, and food (e.g., bush meat) that provide rural communities with livelihood maintenance and an income security buffer between seasonal cash flows (Malleson et al. 2014; FAO 2018). Over 30\% of household income in Ghana derives from NWFP (FAO 2018). Forest plantations, such as teak, are other important industries for Ghana's economy (Oduro et al. 2014).

We use insights from a participatory scenario building project in the Atewa-Densu landscape (Meijer et al. 2018) to identify local landscape demands and ambitions. We upscale these demands to the HFZ including the boundaries of the bordering districts, covering an area of $70,053 \mathrm{~km}^{2}$, and including about 21 million inhabitants (Ghana Statistical Service 2016) (Fig. 1). The AtewaDensu landscape is located in the east of the HFZ, stretching over the Eastern and Greater Accra region. It is characterized by the Atewa Range, a protected forest reserve and surrounding buffer zones supporting several communities that live in the forest fringes. The forest is source of the Densu, Birim, and Ayensu rivers that are important for water supply in the surrounding regions. The Atewa forest reserve is a globally significant biodiversity hotspot. About 6 million people inhabit the Atewa-Densu landscape (Meijer et al. 2018). Thus, more than a third of the inhabitants of the case study region are located here.

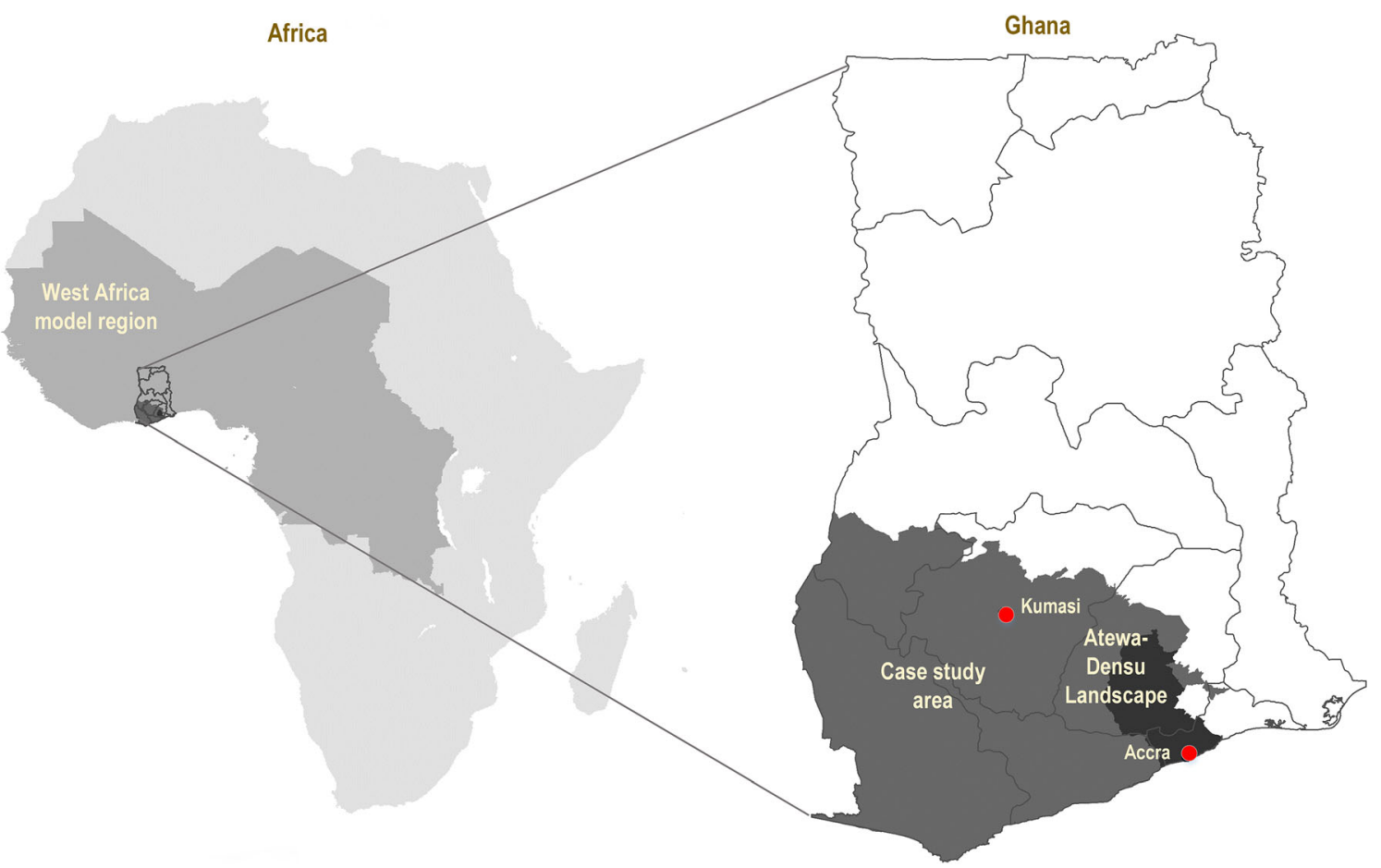

Fig. 1 Case study area including the integrated landscape initiative that was used to upscale to ILM scenario 


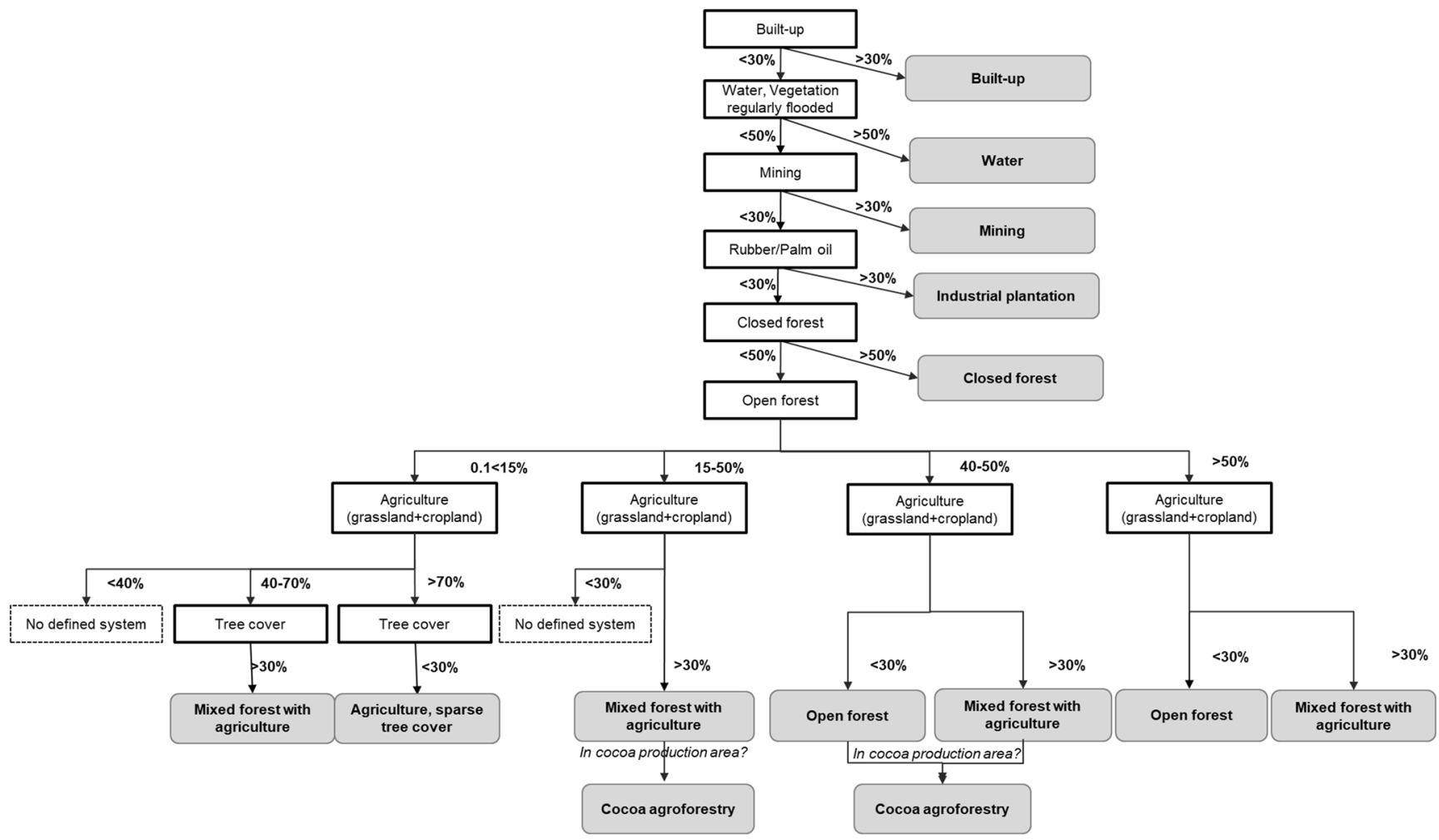

Fig. 2 Hierarchical classification of land systems. Rectangular boxes indicate the land use and land cover classes fed into the land system classification. Rounded gray rectangles indicate the final land system classes used for land change modeling

\section{Method}

The study comprised three steps. First, we constructed a land system map, building on an expert informed classification tree (Fig. 2). We then built the "integrated landscape management" and the "global sustainability" scenario and translated the narratives into land system change simulations, using the land system change model CLUMondo ("Modeling land system change scenarios" section).

\section{Land system classification}

\section{Underlying land cover and land use map}

As no detailed land use map was available that covers the complete HFZ, we first created a land use map by integrating different datasets that provide complementary insights into land use and land cover. All input raster data were resampled to $10 \times$ $10 \mathrm{~m}$. The Climate Change Initiative-S2 prototype land cover map of Africa (ESA 2016) was used as base map, providing the most detailed information on tree cover distribution and density and distinguishing between cropland and grassland (ESA 2016). "Closed forest" and "open forest" were classified using a land cover map of the Forestry Commission (2016b). Rubber plantations were classified using the land cover map of Hackman et al. (2017) for Ghana. The fraction of palm oil plantations was identified in $500 \times 500 \mathrm{~m}$ blocks, based on Sentinel remote sensing data processed by Satelligence (2017) and masked with the land use class "orchards" of Hackman et al. (2017) for more precision. Mining locations were digitalized from a paper map of the Minerals Commission (PBL 2017). ${ }^{1}$ Remaining land cover types were kept, but partly merged to reduce the number of land cover and land use classes fed into the land system classification (Fig. 2).

\section{Land system classification}

Land systems are coupled human-environmental systems that integrate land use and land cover (Verburg et al. 2013). Land systems range from specialized systems, dominated by one land cover/use type (e.g., closed forest or agriculture with sparse tree cover), to mosaic land systems that combine multiple land cover/uses (e.g., mixed forests with agriculture). Consequently, specialized land systems can produce large amounts of specific goods or services, while mosaic land systems can contribute to meet multiple demands. A shift from a mosaic land system to a land system dominated by one land use type is referred to as specialization (Wolff et al. 2018).

To develop a land system map, we first aggregated the land cover/use map ("Underlying land cover and land use map" section) into $200 \times 200 \mathrm{~m}$ resolution layers representing the

\footnotetext{
${ }^{1}$ PBL (2017) manual digitization of mining areas in the Ghana HFZ from the ESRI Imagery base map, accessed via ArcGIS Online.
} 
percentage covered by each land cover/use type. This resolution was chosen to be able to combine the different land uses (i.e., settlement area, agriculture, and forest types) in mosaic land systems. These layers were fed into an expert-based hierarchical classification tree (Fig. 2) that defines land systems based on combinations of percentage of land cover and land use. For example, "agriculture with sparse tree cover" is composed of a combination of up to $0-15 \%$ open forest, more than $70 \%$ agriculture, and less than $30 \%$ tree cover (Fig. 2).

We first identified the land systems "built-up," "water," "mining," "industrial plantations" (including rubber/palm oil), and "closed forest." The remaining open forest area was classified to "mixed forest with agriculture," "agriculture with sparse tree cover," and "open forest," based on combinations of open forest, agriculture, and tree cover density. To identify "cocoa agroforestry," we overlaid the land system classes "mixed forest with agriculture" and "open forest" with polygons specifying mixed arable-cocoa production systems (CERSGIS $2000^{2}$ ). Corresponding areas were classified as "cocoa agroforestry." The final land system map is shown in Figs. $4 \mathrm{a}$ and 7 of the Appendix. The sharp boundaries of the closed forest visible on the map are not a mapping artifact, but reflect the boundaries of the protected forest reserves that are also easily seen from remote sensing images.

\section{Modeling land system change scenarios}

\section{CLUMondo}

We model land system change at a spatial resolution of $200 \times$ $200 \mathrm{~m}$, in our case study area of $70,053 \mathrm{~km}^{2}$ with CLUMondo. CLUMondo is a spatially explicit land system change model (van Asselen and Verburg 2012). With CLUMondo, land system change is allocated responding to competing demands for goods and services, local suitability, and conversion rules that represent legacy effects, time lags, specific land change trajectories, and land use policies. Each land system can produce a range of goods and services that contribute to meet demand. Upon a high demand for a service, land systems that provide more of that service compared to the current land system at that location are given competitive advantage. However, preferences can be given to specific land systems, while others may be excluded as an option to meet that demand, dependent on the scenario narrative. Local suitability is defined as the suitability of a location for a specific land system and is estimated based on empirical relationships between current spatial patterns of each land system (i.e., response variable) and a set of socioeconomic and biophysical location factors (i.e., predictors) using a logistic regression model (van Vliet and Verburg 2018). The logistic regression model calculates the probability of a land system to occur at a specific location.

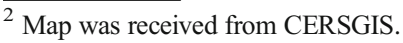

Besides socioeconomic and biophysical factors, policies and regulations can influence local suitability for a specific land system or can restrict LUC completely. For example, restoration policies can favor specific land systems or can fully restrict land system change in protected areas. To account for such factors, a location-specific weight (i.e., locationspecific preference addition) for a land system can be included that influences the estimated local suitability. The areas for which these weights apply are defined in spatial layers. Local suitability can be influenced by neighboring land uses. This is implemented for urbanization where the amount of existing urban areas in the neighborhood increases the local suitability. Furthermore, conversion resistance indicates the difficulty/cost of changing the existing land system at a location and can differ between scenarios to reflect policy incentives, restrictions, available technology, or societal attitudes. The simulated allocation of land system change is thus a function of differential local suitability for different land systems, current land use, conversion or exclusion restrictions, and the competitive advantage of the different land systems in fulfilling the demand for goods and services. The numerical algorithm of the model calculates land system change by matching the land system allocation with externally specified demands. Documentation of the model and its open-source code are available at www.environmentalgeography.nl.

\section{Creation and use of bottom-up and top-down scenarios}

We compare two scenarios: the ILM and the global sustainability scenario (GS). The ILM scenario was inspired by stakeholder discussions within an ILM initiative in the Atewa-Densu region over a 2-year period (IUCN 2016; Meijer et al. 2018). The GS scenario was built following the narratives of the shared socioeconomic pathway 1 (SSP1) "Taking a Green Road" (O'Neill et al. 2017; Popp et al. 2017) using respective outputs of the IMAGE global IAM (Doelman et al. 2018), business-as-usual projections based on statistical data (FAOSTAT 2018), and global environmental policy aspirations that focus on global climate and nature conservation priorities (CBD 2011; UNCCD 2012; UN 2015). Scenarios do not represent definite truths for the future of the region but project a set of plausible pathways of how the future might unfold under contrasting assumptions (Alcamo et al. 2006). Our scenarios are exploratory, due to high uncertainties on how both global and local demands will manifest in the landscape, in the context of the complex land tenure and governance structures in the HFZ (Hansen et al. 2009; Damnyag et al. 2012). We focus on exploring plausible consequences of, in particular, regional and global sustainability aspirations on land system changes in the HFZ without taking into account restrictive aspects of governance. The focus of our scenarios is on land use-related sectors. 
To develop the scenarios, we used two different approaches: a bottom-up and a top-down approach. For the ILM scenario, we used the storyline and input of a stakeholder workshop of the smaller Atewa-Densu landscape and upscaled these to the HFZ. For the GS scenario, we downscaled the narrative of the SSP1 and the respective land use futures for West Africa and Ghana (depending on data availability) to the HFZ (Fig. 3). The GS scenario is used as a comparative scenario, as it follows similar "sustainability" aspirations as the ILM scenario, but from a global perspective. A comparison can thus depict trade-offs and synergies between sustainability aspirations and trends across the local and global scale until 2030. Scenarios represent two extreme cases, with internal consistency that would not be achieved in real life, and a world that might emerge under such scenario conditions. They can thus provide guidance for discussion, e.g., on finding synergies of objectives in the landscape, rather than prediction (van Notten 2008).

\section{Integrated landscape management scenario "regional visions of the landscape}

Description In the ILM scenario, the emphasis is put on achieving shared landscape ambitions that were locally derived from various stakeholder consultations and workshops in the Atewa-Densu landscape (Fig. 1). Participants included 37 stakeholders from different sectors and scales. These consisted of governmental officials (of the Ministry of Agriculture, Water Resources Commission, Minerals Commission, Environmental Protection Agency, Forestry Commission, and the Cocoa board of the Eastern region), the private sector (Newmont mining, BESNet Blue Skies), NGOs representing farmers and local communities (A Rocha Ghana, Solidaridad, and IUCN-NL), coordinating directors and planners of municipal assemblies of the eleven districts included in the landscape, as well as scientists of the University College for Environment and Agriculture (UCEAS) (Appendix, Table 4). During a workshop, the stakeholders discussed their collective ambitions for the landscape (Meijer et al. 2018). These included improved food security and livelihoods, conservation of forest ecosystems and protection of biodiversity, sustainable management of water resources, sustainable cocoa and palm oil production, and maintaining functioning buffer zones by promoting agroforestry and halting mining activities. These landscape ambitions also align with national development ambitions reflected in national development plans, including the Medium-Term National

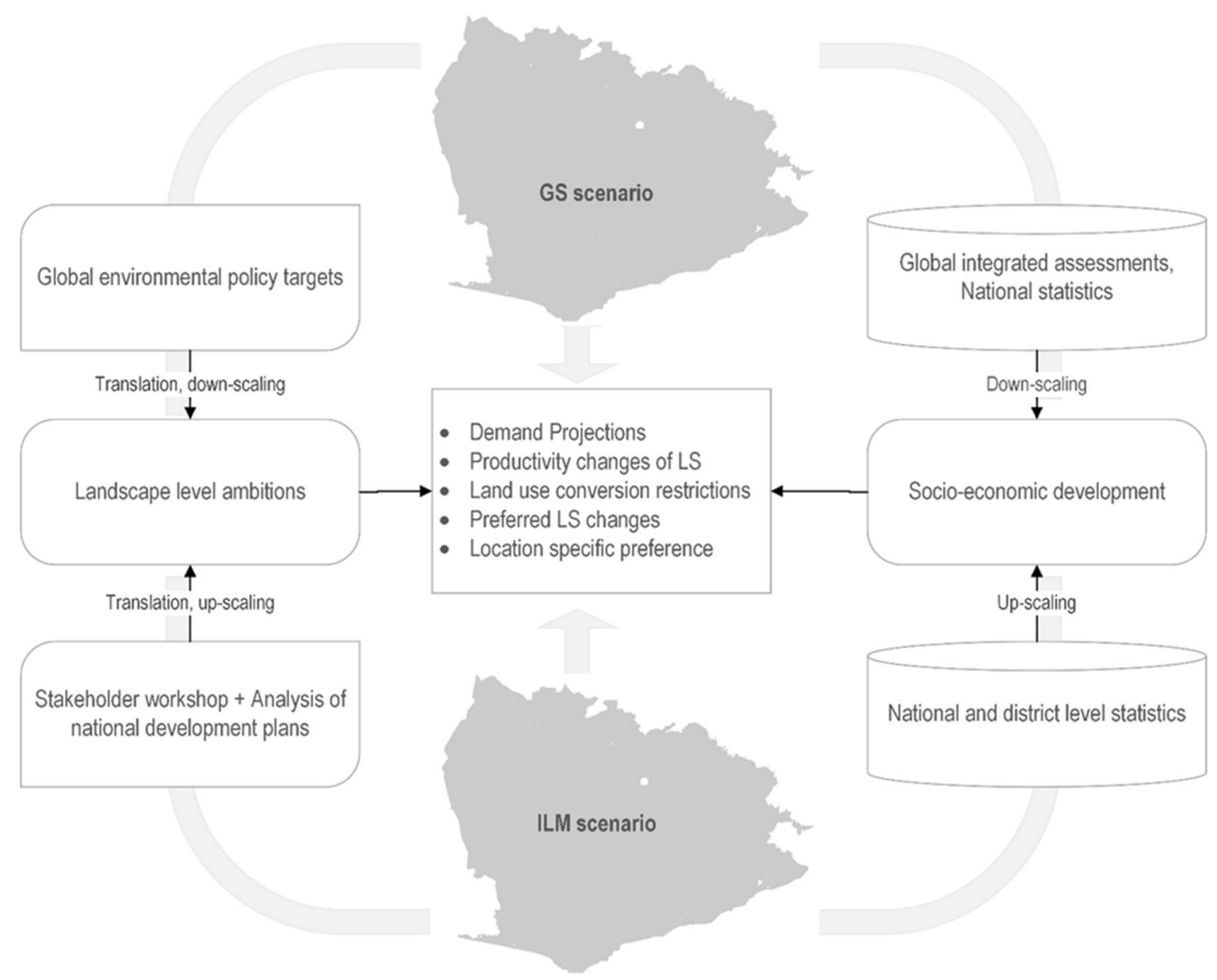

Fig. 3 Overview of the scenario approach and sources of information feeding into the scenarios (LS = land systems) 
Development Policy Framework, the Ghana Shared Growth and Development Agenda II (GSGDA II), and the National Integrated Water Management Plan. Additional to the stakeholder input, these national development plans were used to identify national land use ambitions for the HFZ that go beyond those defined for the landscape only, i.e., sustainable urban development. Thus, while the scenario is locally informed, it reflects the sustainability ambitions of both localand national-level stakeholders.

Extrapolating these ambitions from the Atewa-Densu landscape to the HFZ resulted in a set of scenario assumptions that include the objective to improve food security and livelihoods and increase agricultural production in line with the interventions of the Shared Growth and Development Agenda, the main poverty reduction strategy of Ghana (National Development Planning Commission 2017). Agricultural production remains concentrated in designated highly productive areas. To protect and conserve forest biodiversity, forest degradation is reduced in natural closed forests. Degraded forest areas are restored, contributing to the countries' forest plantation strategy (Forestry Commission 2016a). Mining regulations are enforced that prohibit mining activities in protected areas, protected area buffer zones, and riparian buffer zones. Water resources are managed sustainably by protecting riparian buffer zones in line with the National Integrated Water Resources Management Plan (Water Resources Commission 2012) and riparian buffer zone policies (Government of Ghana 2011). Urban development is controlled and dense, focusing on the main urban centers Accra and Kumasi. Growth is encouraged in the medium rather than small urban settlements. Green belts are planned around urban areas to protect against settlement amalgamation (Government of Ghana 2015). Population growth follows historical trends between 2000 and 2015 in the respective districts (Ghana Statistical Service 2016). Demand for industrial crops increases in line with global trends. Due to yield enhancements and effective regulations, expansion of these crops is limited.

Quantification-This scenario is driven by five demand types: built-up area, tree cover area, tons of industrial crops (incl. rubber and palm oil), tons of agriculture crops, and tons of cocoa. To calculate the demand for industrial, agricultural, and cocoa crops, national crop production data (FAOSTAT 2018) was downscaled to the case study region by allocating the total respective demand in 2015 (e.g., crop production) to the respective land cover area (e.g., cropland) in 2015, not distinguishing between the intensity of production. For these crops, we thus assume demand to be equal to production. The demand for urban area is based on the built-up area in the case study region in 2015 (ESA 2016). Changes in built-up area were calculated based on population increases in the respective districts, between 2000 and 2016 (Ghana Statistical Service 2016). Tree cover demand was calculated based on tree cover in 2015 (ESA 2016), minus degraded forest area (National REDD+ Secretariat 2017), plus the forest restoration targets set for 2030 (IUCN 2018; Forestry Commission 2016a, b).
To calculate the forest restoration target for the region, the national forest restoration target was attributed to the case study area, relative to the area of degraded open forest $\left(6854.47 \mathrm{~km}^{2}\right)$. This area equals $41 \%$ of the total national restoration target $\left(16,672 \mathrm{~km}^{2}\right)$ set for the Bonn challenge (IUCN 2018). Additionally, the area identified for plantation expansion by the Forestry Commission of Ghana was added as an area target to meet the national plantation strategy 2016-2040 (Forestry Commission 2016a). This strategy closely links to the forest restoration target and accounts for expected increases in timber demand. Total crop production is composed of crops that dominate production in the case study region, including cassava, plantain, and maize. The respective share of each crop produced in the case study region relative to national production was calculated based on the respective share of the cropland area in this region. Demand changes for these crops were extrapolated in line with historical growth rates of 2000-2015 (FAOSTAT 2018) and population changes. Cocoa demand was calculated using historical growth rates of cocoa bean production (FAOSTAT 2018). Increases in crop yields follow scenario estimates for the West Africa region (Doelman et al. 2018). To model the protection and conservation of forest biodiversity, closed forest in forest reserves and riparian buffer zones were restricted from LUC. Following sustainable water management targets, mining activities are discontinued in protected areas and riparian buffer zones and might be converted to other land systems. To model dense urban development, the impact of neighboring land uses on the local suitability was increased for urban areas. Additionally, local suitability for urban development in a radius of $400 \mathrm{~m}$ around medium- and large-sized cities was increased by adding a positive location-specific weight. Green belts were modeled by increasing local suitability for forest systems around smaller urban settlements $\left(<100\right.$ cells $\left./ 4 \mathrm{~km}^{2}\right)$ to protect against settlement amalgamation.

\section{Global sustainability scenario}

Description In the GS scenario, development priorities follow "sustainable development" that considers environmental boundaries and societal well-being. Land resources are managed sustainably, and there is increasing commitment to achieving SDGs, with a focus on climate change mitigation. In an open global economy, food and other goods are traded internationally (O’Neill et al. 2017). International cooperation for climate change mitigation removes delays in achieving climate change mitigation targets. There is full participation of the land use sector. Concerns linked to deforestation and its impact on global forest biodiversity, cocoa production supply, and carbon emissions in the HFZ increase interest to combine agricultural/cocoa production and climate change mitigation in "climate-smart" land systems (e.g., REDD+ and forest restoration). Following the National REDD+ strategy for Ghana (Forestry Commission 2016b) and the Forest 
Investment Strategy (World Bank 2015), the productivity of cocoa farming increases, reducing the need for farmers to expand or relocate their farms, which reduces deforestation and carbon emissions. Due to strict LUC regulations, deforestation is strongly reduced (Popp et al. 2017; Doelman et al. 2018). Crop yields are rapidly increasing due to large investments in technological innovation. Population growth follows the same historical trends as in the ILM scenario (Ghana Statistical Service 2016), and urban development is controlled and dense. Biodiversity is conserved by reducing the loss of native closed forest and by establishing buffer zones around closed forest reserves. Increases in the demanded wood and timber are met primarily by timber plantations in degraded forest areas (i.e., within forest reserves). Due to global environmental concerns linked to palm oil plantations such as deforestation, biodiversity loss, and water depletion, as well as investment insecurities, the demand for palm oil decreases. Rubber crops remain, and productivity increases.

\section{Quantification}

To calculate demands, projections of global IAMs for West Africa (Doelman et al. 2018) were compared with national data (FAOSTAT 2018) and then downscaled to the HFZ. As in the ILM scenario, this was done by allocating the relative share of demand in 2015 (e.g., crop production) to the respective land cover area (e.g., cropland) in 2015, not distinguishing between the intensity of production. Built-up area is driven by projected growth rates in population for Ghana following IMAGE projections for the years 2010, 2020, and 2030 (Kc and Lutz 2014). These population projections are similar to the ILM scenario; however, under the assumption of stricter control of urban sprawl, there is less built-up area expansion, compared to ILM. Tree cover demand was calculated similar to the ILM scenario, following the same forest restoration targets (i.e., Bonn challenge). Total crop production is calculated as in the ILM scenario. The demand for crop production and cocoa, as well as productivity increases, follows IMAGE calculations for West Africa (Doelman et al. 2018). As part of climate change mitigation efforts (REDD+), climate-smart land systems, including cocoa agroforestry and mixed forest-agriculture systems, experience slightly higher productivity increases compared to agricultural dominated land systems. These mixed land systems are preferred in degraded forest areas due to their multifunctionality to contribute to carbon sequestration, food security, and livelihoods. Rubber demand increases following historical trends (FAOSTAT 2018). A decline in palm oil demand, however, results in an overall decline in demand for industrial plantations. To conserve biodiversity, closed forest in national and international designated forest reserves is protected from LUC (CBD 2011). In the remaining areas of the reserves and adjacent to them, restoration of closed forests is incentivized by adding a location-specific preference addition to the calculated local suitability of closed forest in these areas (Appendix, Table 10).

\section{Identification of synergies and trade-offs in landscape sustainability dimensions}

We selected sustainability indicators to measure the consequences of the scenarios ("Trade-offs and synergies within landscape sustainability dimensions" section) for regional sustainability. These indicators measure how the resulting land system architecture scores with regard to food production, forest biodiversity, climate change mitigation, and urbanization. These dimensions were selected as they cover the main land use ambitions and demands identified at each spatial scale (Table 1). The rationale for indicator selection and calculation can be found in the Appendix, Table 15.

Table 1 Sustainability dimensions and indicators selected for analysis

\begin{tabular}{ll}
\hline SDG & Indicators \\
\hline SDG 2: Zero hunger (Food production) & $\begin{array}{l}\text { Diversity in agricultural systems } \\
\text { Agricultural production per person } \\
\text { Increase in agricultural production in poorer districts } \\
\text { Area of subsistence agriculture per person }\end{array}$ \\
Area of commercial agriculture per person \\
SDG15: Life on land (Forest biodiversity) & Change in closed forest area \\
& Conversion of initial closed forest area \\
SDG13: Climate action (Climate change mitigation) & Change in forest patch size \\
& Net loss of closed forest \\
Carbon emissions from conversion of forest to cocoa agroforestry & Change in climate smart agroforestry in degraded areas \\
SDG1: Sustainable cities and communities (Sustainable urbanization) & Change in settlement size -small to larger settlements \\
Change of forest systems in green belts
\end{tabular}




\section{Results}

We first compare land system changes in the HFZ between 2015 and 2030 as a result of the different landscape demands defined in the ILM and the GS scenario. We then analyze each scenario in terms of food production, forest biodiversity conservation, climate change mitigation, and urbanization.
Finally, we assess trade-offs and synergies in the landscape between the respective sustainability dimensions.

\section{Land system changes}

Figure 4 shows the simulated land system changes between 2015 and 2030 under the ILM and GS scenarios. Both
Fig. 4 Land systems in 2015 (a) and 2030 under the ILM (b) and GS (c) scenarios a

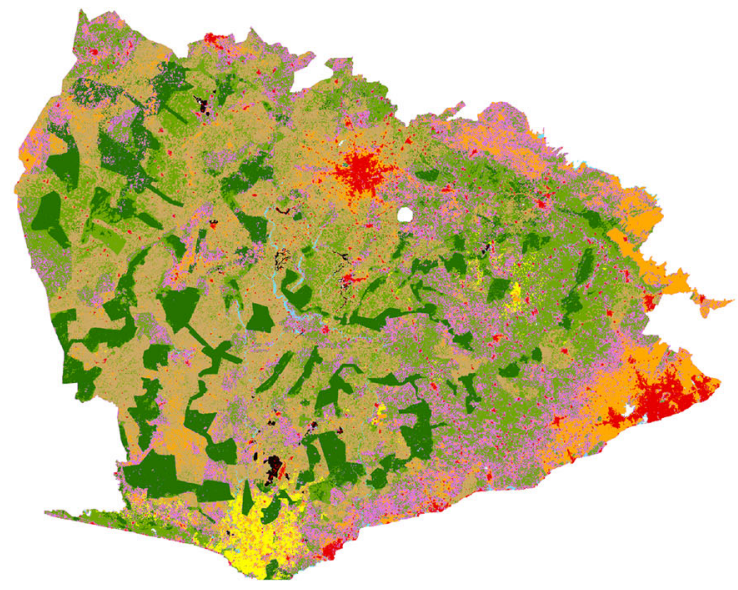

b

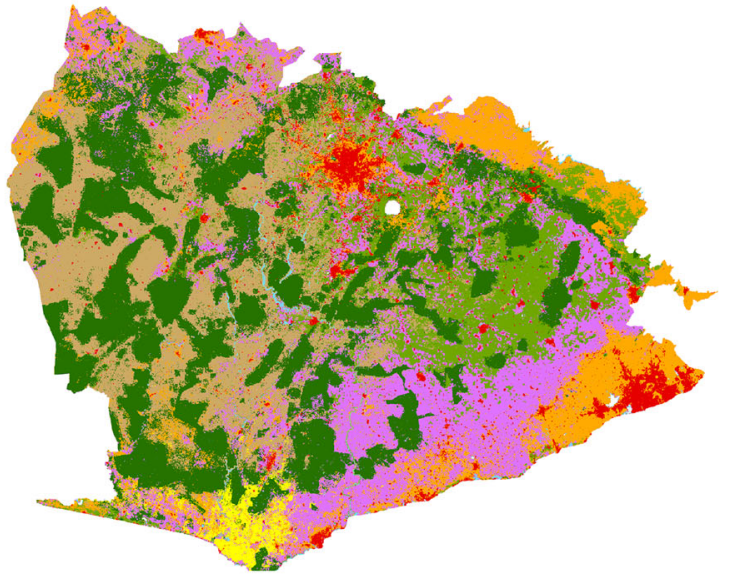

C

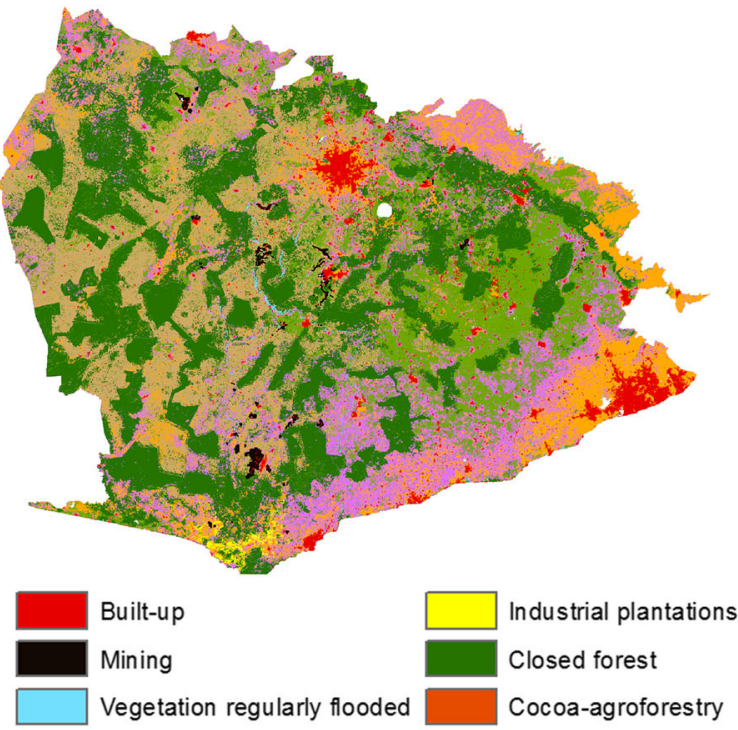

Demand increase (\%)

\begin{tabular}{ll}
\hline Built-up (area) & $40 \%$ \\
Tree cover (area) & $18 \%$ \\
Industrial plantations (tons) & $47 \%$ \\
Agricultural crops (tons) & $55 \%$ \\
Cocoa crops (tons) & $17 \%$
\end{tabular}

Demand increase (\%)

Built-up (area) 21\%

Tree cover (area) $\quad 18 \%$

Industrial plantations (tons) $\quad-50 \%$

Agricultural crops (tons) $\quad 68 \%$

Cocoa crops (tons) 
scenarios reflect outcomes of sustainability ambitions and it is not surprising that both show a greener future (i.e., tree cover) and a strong deviation from recent trends in land system change. The ILM scenario shows strong expansion of mixed forest with agriculture in the southeast of the study region. Agriculture with sparse tree cover remains concentrated around Accra and expands in the northeast. In the GS scenario, the growing demand for agriculture is primarily met by productivity increases in the more specialized agricultural systems. These land systems produce more crops per square kilometer, resulting in a decrease of mixed forest with agriculture. The area of industrial plantations decreases under both scenarios. Yield enhancements reduce the total production area and result in the restoration of old plantations to closed forest and open forest. In the GS scenario, the decreased demand for palm oil triggers contraction of palm oil plantations, particularly in the south of the region. Cocoa agroforestry increases under both scenarios and concentrates in the western part of the region. Here, cocoa agroforestry replaces particularly open forests, which shift to the east, where they expand. Due to increased demand for forest restoration and timber, the

\section{Food production (SDG 2) \\ Diversity of agricultural systems (Ratio mixed/specialized agri systems) \\ Agricultural production per person (Ratio crop production/people) \\ Subsistence agricultural production per 100 people (Ratio agri production from subsistence/population) \\ Commercial agriculture per person (Ratio commercial agri/population) \\ Increase agricultural production in poorer districts (\% increase agri production in districts with poverty rate $>25 \%$ )}

\section{Forest biodiversity conservation (SDG 15)}

Change in closed forest area (Ratio forest area compared to 2015)

Conversion of initial closed forest area (\%area converted to other land systems)

Forest patch size (Ratio of larger $>845 \mathrm{~km} 2$ to smaller closed forest patches)

Net loss of closed forest area

Climate change mitigation (SDG 13)

Carbon emissions (Mt) from conversion of forest systems to cocoa agroforestry (Ratio ILM/GS scenario)

Change in climate smart agriculture in degraded areas (Change area climate smart agriculture relative to 2015)

\section{Urbanization (SDG 11)}

Built-up expansion into forest and agricultural land systems (Ratio to other land systems)

Change in settlement size (Change small settlements $<8.4 \mathrm{~km} 2 /$ larger settlements)

Change in share of forest systems in green belts (\% relative to other land systems in 2015) area of closed forest increases under both scenarios. Closed forests are gained particularly in the buffer zones of initial closed forest reserves where they replace open and mixed forest systems. As a result of the riparian zone policies in the ILM scenario, mining decreases in riparian buffer zones. Abandoned mining sites are restored with mixed forest and agriculture and closed forest. In the GS scenario, further expansion of mining converts initial closed forest areas, inducing forest degradation within and outside riparian buffer zones. Due to the growing population, built-up area increases in both scenarios. In the ILM scenario, less compact urban development results in large urban expansion. Land system changes in square kilometers between 2015 and 2030 in the ILM and GS scenario can be seen in Fig. 9 of the Appendix.

\section{Trade-offs and synergies within landscape sustainability dimensions}

Figure 5 shows how the scenarios scored on the different indicators related to food production, forest biodiversity conservation, climate change mitigation, and urbanization. The

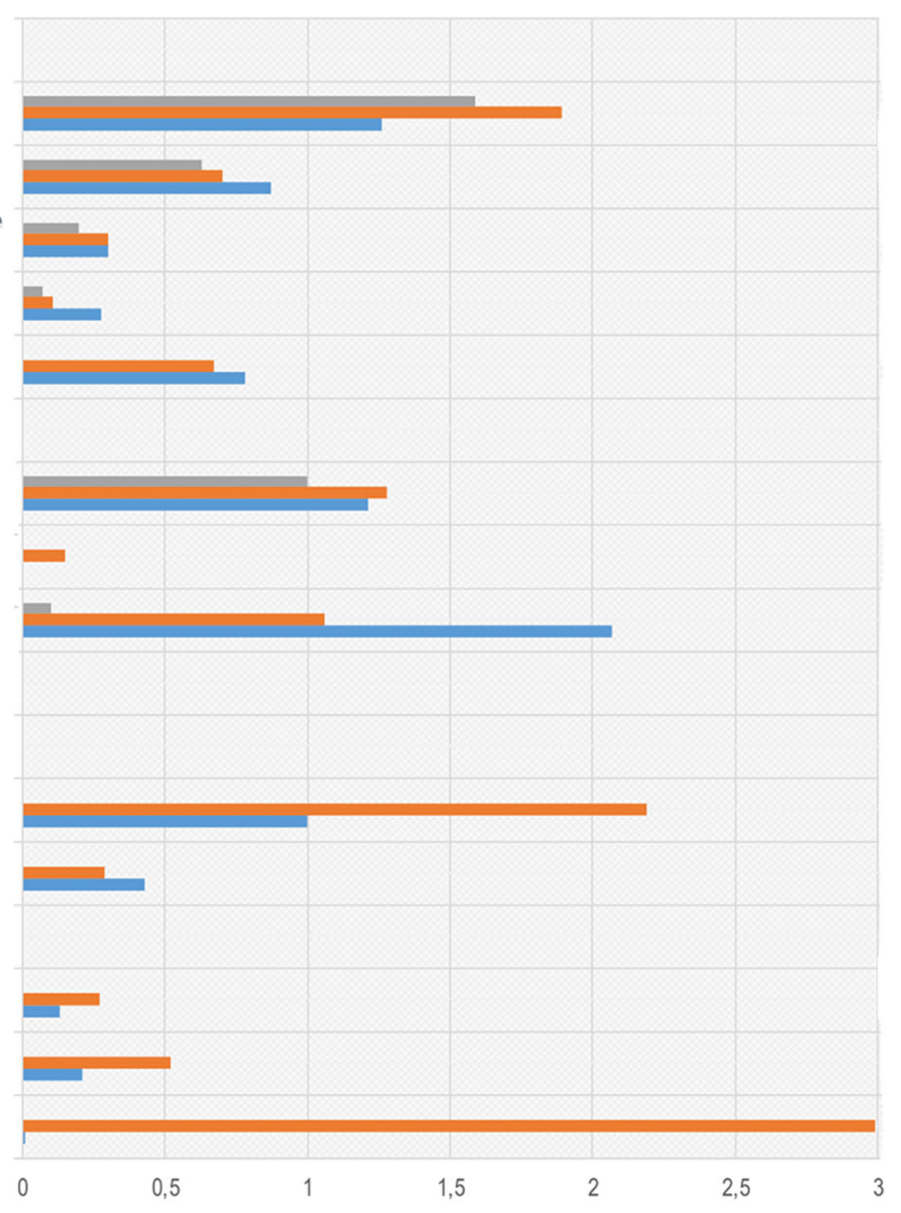

Fig. 5 Indicators to assess synergies and trade-offs between the ILM and GS scenarios 
results are presented in ratios between the ILM and GS scenarios or percentage change relative to 2015 (the absolute numbers can be found in the Appendix, Table 16).

\section{Food production}

Diversity of agricultural systems increases in the ILM scenario and decreases in the GS scenario. In the ILM scenario, agricultural demand is mainly met by mixed forest with agriculture systems. The GS scenario, in contrast, shows a slightly larger expansion of the specialized agriculture with sparse tree cover systems and a decrease in mixed forest systems. Compared to 2015, the peopleto-cropland ratio increases in both scenarios and more calories are supplied, with a slightly higher increase in the GS scenario. In both scenarios, poorer regions benefit from agricultural production increase, but in the GS scenario, agricultural production increases more in districts with higher poverty headcounts compared to the ILM scenario (Fig. 6). In both scenarios, the area of subsistence and commercial agriculture decreases. The decrease in the area of subsistence agriculture is larger in ILM (-27\% vs. $-17 \%$ ), particularly due to strong declines in open forest systems; the decrease in commercial agriculture is larger in the GS scenario $(-17 \%$ vs. $-28 \%)$, particularly due to higher productivity increases. Subsistence agricultural production increases similarly in both scenarios. Commercial agriculture per person increases more in the GS scenario.

\section{Forest biodiversity conservation}

The ILM scenario shows a higher gain in closed forest than the GS scenario (128\% vs. $121 \%$ ). In both scenarios, gains occur particularly in buffer zones of initial closed forest reserves, resulting in larger forest patches compared to 2015. In the GS scenario, initial closed forest areas remain intact. In the ILM scenario, smaller areas of intact closed forest are converted to open forest in the northeast of the region. This results in larger patches of closed forest in the GS scenario and slightly higher forest fragmentation in the ILM scenario.

\section{Climate change mitigation}

In both scenarios, gains in tree cover and forest density contribute to climate change mitigation. In the ILM scenario, more than twice the area of closed and open forest is converted to cocoa agroforestry, resulting in more than twice the carbon emissions ( $7.43 \mathrm{CO}_{2}$ megatons) compared to the GS scenario (3.4 $\mathrm{CO}_{2}$ megatons). This can be associated with lower yield enhancements of cocoa agroforestry systems and less targeted planting of these land systems in degraded forest areas. In contrast, higher yield enhancements of cocoa lead to less forest conversion to cocoa in the GS scenario. Compared to 2015, climate-smart agriculture increases in degraded forest areas. These increases are slightly higher in the GS scenario.
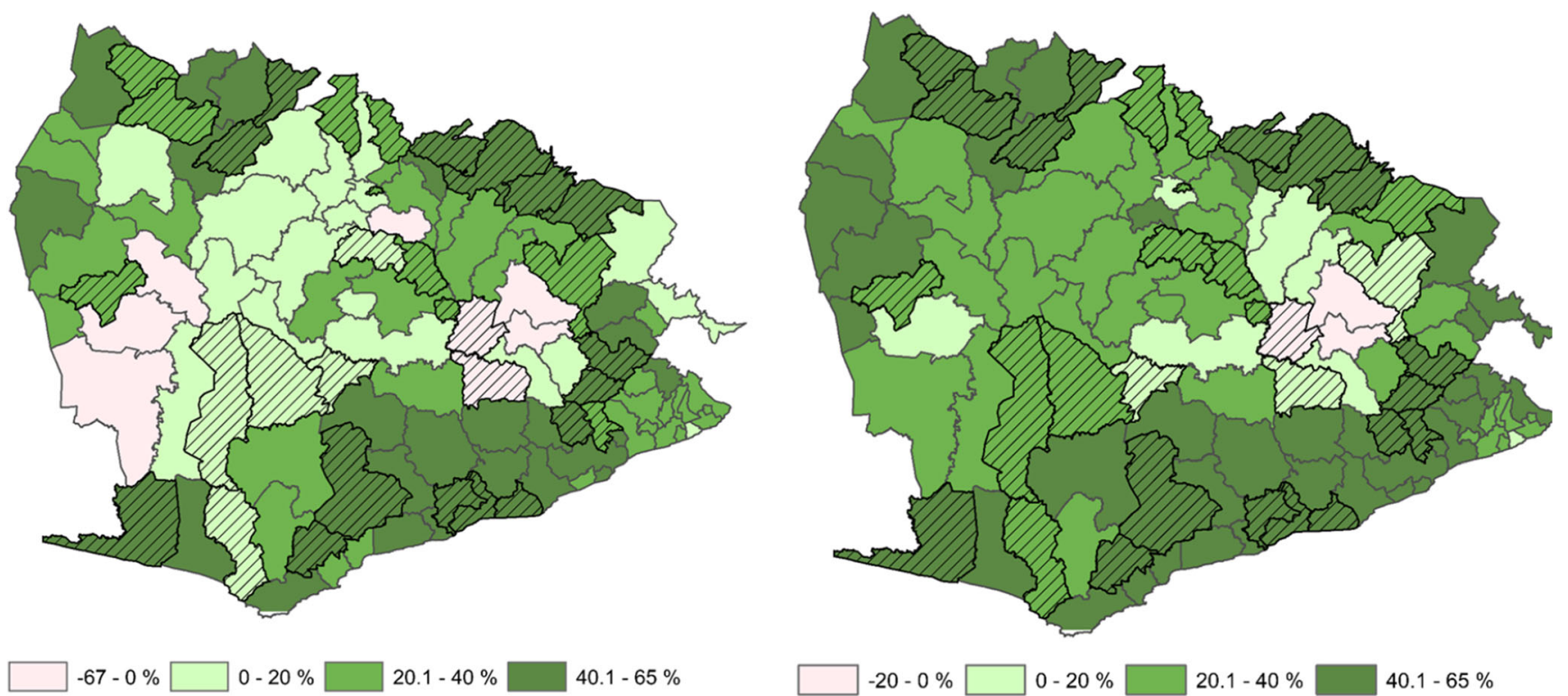

$20-0 \% \square 0-20 \%$

$20.1-40 \%$

$40.1-65 \%$

Fig. 6 Percentage change in agricultural production per district between 2015 and 2030 in the ILM (left) and GS (right) scenario. Districts highlighted with the hatched line are those with a poverty head count over $25 \%$ 


\section{Urbanization}

In both scenarios, urban expansion occurs at the cost of forest and agricultural systems. In particular, mosaic forest systems (cocoa agroforestry and mixed forest with agriculture) are converted to built-up area. In the ILM scenario, larger expansion of built-up area comes at a higher cost of these land systems and, consequently, a higher impact on nature, compared to the GS scenario. In the ILM scenario, built-up expansion occurs mainly within smaller settlements, improving the connectivity between settlements. The area of forest in urban green belts ( $1 \mathrm{~km}$ radius) increases under both scenarios. In the ILM scenario, these increases are higher particularly in regard to open forest, increasing access to forests (Appendix, Fig. 9).

\section{Discussion}

\section{Trade-offs and synergies in the integrated landscape management scenario}

The comparison between scenarios suggests that global conservation priorities and local land use ambitions, even though they both aim at a sustainable future, can result in different local land system architectures with consequences for food production, forest biodiversity conservation, climate change mitigation, and urbanization. These differences are mainly the result of different prioritization of landscape functions at different spatial scales and associated differences in agricultural yield investments. From the local landscape-scale perspective, integration of food security, forest biodiversity conservation, and sustainable water management is important. From a global market and climate perspective, the HFZ is of particular interest for cocoa production and forest protection contributing to climate change mitigation.

These differences induced patterns of land sharing in the ILM scenario and a trend of land use specialization in the GS scenario in the study region. These patterns are also found in empirical studies that indicate that land sparing is more often favored to conserve tropical forest biodiversity, whereas land sharing is more often favored to enhance agrobiodiversity, ES provision, and food security (Luskin et al. 2018). In the ILM scenario, larger gains in the diversity of agricultural systems and planned green belts around medium and larger settlements increased the coverage of forest systems in green belts, potentially enhancing people's access to forest systems and the ES they provide (Tsai et al. 2019). Agricultural diversity can enhance household food security (i.e., dietary diversity) and alleviate poverty by combining different production items in the landscape (Asante et al. 2018; Ecker 2018). Increased land sharing in mixed forest systems resulted in fewer gains of agricultural production in poorer regions compared to the GS scenario. However, given expected climate change impacts on the region, such landscapes can offer opportunities for climate change adaptation to reduce the vulnerability of smallholder incomes through farm diversification (Schroth et al. 2016; Bunn et al. 2019). Besides, mixed forest systems with crop-grass-tree combinations can mimic the ecological structure of natural habitats at smaller spatial scales and can contribute to biodiversity conservation.

Due to lower yield enhancements of cocoa agroforestry in the ILM scenario, cocoa agroforestry converted larger areas of open and closed forest systems compared with the GS scenario. This resulted in slightly more forest fragmentation, with potential impacts on biodiversity and twice the $\mathrm{CO}_{2}$ emissions compared with the GS scenario. Lower yield enhancements in agricultural systems and cocoa agroforestry came at the expense of climate change mitigation and the possibility of protecting larger patches of closed forest for biodiversity conservation.

The ILM scenario created more multifunctional land systems in the immediate neighborhood of the settlements, in particular the Atewa forest landscape that provides multiple ES to local communities. At the scale of the study area, however, the GS scenario showed fewer trade-offs between the analyzed sustainability dimensions than the ILM scenario. This is primarily due to increased agricultural specialization and, in line with SSP1, increased efforts to increase agricultural production efficiency. This can be considered consistent with Palazzo et al. (2016) who expect that $66 \%$ of production increases in a sustainability scenario for West Africa are due to yield increases. Agricultural specialization increased crop production with potential benefits to poorer districts that are more strongly dependent on production gains for subsistence. Efficiency gains in agricultural production allowed to protect intact closed forest areas from agricultural encroachment and to reforest adjacent buffer areas, increasing forest patch size favorable to conserve forest biodiversity. Efficiency gains in agricultural and cocoa production, in combination with targeting cocoa agroforestry in degraded forest areas outside forest reserves, reduce the area of deforestation and associated $\mathrm{CO}_{2}$ emissions, thus creating synergies with climate change mitigation. This is consistent with other studies that identified sustainable intensification of cocoa agroforestry as a promising REDD+ strategy in West Africa, to avoid deforestation and land degradation and to achieve wider sustainability benefits (Gockowski and Sonwa 2011; Minang et al. 2014). More efficient urbanization in relatively larger settlements can reduce the risk of forest loss to built-up area (Tsai et al. 2019). In the GS scenario, compact urbanization saved a larger share of agricultural land from built-up expansion, also contributing to climate change mitigation and forest biodiversity conservation.

\section{Implications for integrated landscape management}

The results of our land change scenarios highlight potential impacts of both local and global sustainability ambitions 
linked to food production, forest biodiversity conservation, and climate change mitigation on the land system architecture of the HFZ. Due to the high uncertainty of drivers and their future manifestation in the landscape, in particular related to governance and land tenure structures in the region, our scenarios should be understood as boundary objects for discussions on how alternative futures could look like in the landscape (Bürgi et al. 2017).

The comparison between scenarios suggests that global climate priorities and growing demand for agriculture can result in a land system architecture favoring patterns of land sparing at the scale of the HFZ. These differences to the ILM scenario result particularly from larger required investments in agricultural yields and targeted planting of cocoa agroforestry in degraded forest areas. These interventions allowed for synergies with food production, climate change mitigation, and forest biodiversity conservation at the scale of the study region but reduced the area of mixed forest with agriculture that combines landscape services at smaller spatial scales, such as agricultural diversity and access to forest mosaics. Thus, in the context of different interests in the region and expected impacts of climate change, adaptation strategies, such as sustainable intensification of agroforestry and the diversification of crops, can be useful to secure multiple interests across the landscape (Schroth et al. 2016; Bunn et al. 2019). In this context, there are several synergies between climate change mitigation efforts and climate change adaptation in forest systems that are inherent to forest landscape restoration and climate-smart forest management (e.g., REDD+) (FAO 2010). While these synergies were not directly quantified, agroforestry and mixed forest systems can both contribute to climate change mitigation as well as reduce the vulnerability of local livelihoods by providing NWFP and firewood in case of drought-related crop failure, as well as regulate water flow during heavy rainfall (Rizvi et al. 2015).

Between 2015 and 2030, the population in Ghana is expected to almost double (UN 2019). Most of this population increase is expected in the HFZ given that $75 \%$ of the Ghanaian population is concentrated here (Ghana Statistical Service 2016). The scenarios showed that urban expansion could occur at the cost of forest and agricultural systems, in particular mixed forest and cocoa agroforestry landscapes that provide multiple benefits to local communities. Compact, planned urbanization will thus be important to align multiple demands in the landscape. To keep forest landscapes accessible, planned green belts can ensure that these remain accessible to local people and are not being spared to distant, potentially inaccessible areas.

Context-dependent indicators that can measure the impact of different landscape requirements on sustainability goals over time, as has been explored in this study, can be the first step in monitoring progress of ILM initiatives in implementing subnational commitments in connection with the SDGs (Bürgi et al. 2017). Such indicators have been lacking so far, which is seen as a key barrier of successful monitoring and upscaling of ILM initiatives (Milder et al. 2014; Reed et al. 2016). The challenge to engage different actors and land users within and outside the landscape has been another barrier for implementing ILM (Reed et al. 2016; Arts et al. 2017). Land change scenarios that aim to clarify and visualize the uncertainties intrinsic to the future can facilitate dialog among key stakeholders and can provide a platform for envisioning what land use ambitions could look like for the landscape (Bürgi et al. 2017; Meijer et al. 2018; Verburg et al. 2019). Such visualizations are common in discussing small-scale landscape interventions (Tieskens et al. 2017; Zagaria et al. 2017) but could play a similar role in the context of shaping subnational frameworks to harmonize with global environmental policy targets.

Achieving sustainable land use across spatial scales will strongly depend on the local context, the actors involved, and their willingness to collaborate and integrate objectives at the landscape scale (Mann et al. 2018). To evaluate and reconcile land use conflicts among different stakeholder interests, a better understanding of the relevant actors is needed, including their power dynamics and land tenure relationships, as well as their role in driving land system changes (Mann et al. 2018). In this study, we identified land use demand based on certain stakeholder inputs, statistics, and policy initiatives. These demands were aggregated to spatial scales, not differentiating the visions of different actors on the multiple scales. To gather the most relevant actors to initiate cross-scale and cross-sectoral dialog and to enhance cooperation and joint policymaking, more insight is needed on the role of global environmental conventions, companies, and governments in influencing specific land change processes locally (Mann et al. 2018).

ILM initiatives depend strongly on external actors for funding (Foli et al. 2018). In Africa, access to continuous funding has so far remained one of the greatest challenges to scale up ILM initiatives (Milder et al. 2014). Land change scenarios can be used to explore the sustainability of ILM initiatives and investment decisions. For example, this can be done by visualizing where in the landscape local needs can be aligned with global climate and conservation targets, accounting for long-term dynamics of the socioeconomic system. This can help to direct funding to specific landscape initiatives. In this way, models can help in assessing the cost-effectiveness of ILM approaches concerning meeting different societal demands or policy targets in the landscape, e.g., to increase flows of ES (Milder et al. 2014). For adapting global policy initiatives, such as REDD+ to the local context, consideration of local traditional knowledge, needs, and policies is indispensable to explore potential governance risks and land use conflicts that could result from such initiatives locally. 


\section{Methodological challenges}

Our land change scenarios have to be interpreted considering the capacities and limitations of the underlying land system map (Appendix, "Land system map" section), the scenarios, and the sustainability indicators. In both scenarios, we considered the land use and sustainability priorities as a consistent and widely agreed set of priorities and assumed that land use ambitions and regulations are fully implemented. While this is a common boundary condition in scenario studies, empirical studies show that REDD+ interventions and protection measures (e.g., for the globally significant biodiversity areas) have not been successful in halting illegal activities in the forest reserves of the HFZ as a result of weak law enforcement and diverging actor priorities (Ankomah et al. 2019). There have been ongoing conflicts between economically driven agricultural expansion into forest reserves and forest conservation priorities, e.g., of the Forestry Commission (Asare et al. 2014; Acheampong et al. 2019). While our scenarios did not account for these uncertainties, which resulted from a lack of data, they can illustrate which necessary interventions and regulations would be needed to achieve a desired land use future, and with that, provide a basis for discussion and decision-making.

To assess trade-offs and synergies in meeting different sustainability ambitions, we selected only a few sustainability indicators that we could measure with available data. The consequences of the scenarios on landscape sustainability were thus not fully evaluated. This applies also for many ES and their contributions to societal well-being. For example, while larger productivity improvements in the GS scenario enhanced synergies between the analyzed sustainability dimensions, they can cause negative effects on ES that were not quantified. Agricultural productivity gains are often achieved through increased fertilizer and pesticide input, which can cause negative effects on river catchments that provide water supply to the region (Ayivor and Gordon 2012). Further expansion of mining that occurred in the GS scenario can cause negative effects beyond forest fragmentation, impacting freshwater resources, biodiversity, and agriculture (Schueler et al. 2011). Furthermore, we associated an increase in agricultural production with increased local benefits, for example contributing to poverty reduction and food security. However, the proportion of benefits that would trickle down to different societal groups is unclear. Due to many assumptions of our model, and the lack of data, the consequences of land changes for the region can only be fully assessed in consultation with local stakeholders.

\section{Land change scenarios to explore synergies and trade-offs in aligning local and global demands in landscapes}

To explore the potential influence of local and global demands on land system change in the HFZ, we applied both a top-down and a bottom-up scenario approach. Usually, top-down scenario modeling has been applied in (global) environmental change studies to inform climate change adaptation (van Vuuren et al. 2007, 2010; Fortes et al. 2013; Nilsson et al. 2017). Top-down scenarios usually account for larger macroeconomic trends, whereas bottom-up scenarios account for more detailed local biophysical and social processes, such as through stakeholder input (Verburg and Overmars 2009). In combination, most studies have used top-down and bottom-up approaches to develop integrated scenarios that account for both global and local drivers (Biggs et al. 2007). We applied each approach separately to identify drivers and land demands from each spatial scale and to assess their aggregated influence in driving land system change locally. This allowed for translating and operationalizing land use ambitions defined in each scenario into spatial interventions while accounting for both regional and global demand. As a result, our scenarios are both exploratory, by contextualizing ILM ambitions and imagining change, and target-based, by showing how different demands can be allocated in the landscape. Such scenarios can serve as boundary objects for discussions on how alternative futures could look like in the landscape (Bürgi et al. 2017), to integrate objectives in the landscapes and to prioritize issues that will further enhance the envisioned futures of a region.

Acknowledgments We thank The Centre for Remote Sensing and Geographic Information Services Ghana/Dr. Foster Mensah for providing access to relevant datasets and Paul Giesen (PBL Netherlands Environmental Assessment Agency) for digitizing the mining locations for the High Forest Zone. This paper has built on part of the project "Modeling the impact of integrated landscape management on achieving the SDGs," conducted by the PBL Netherlands Environmental Assessment Agency and Ecoagriculture Partners.

Funding The authors would like to acknowledge the European Research Council under the European Union's Seventh Framework Programme ERC grant agreement nr. 311819 (GLOLAND) for support.

Open Access This article is licensed under a Creative Commons Attribution 4.0 International License, which permits use, sharing, adaptation, distribution and reproduction in any medium or format, as long as you give appropriate credit to the original author(s) and the source, provide a link to the Creative Commons licence, and indicate if changes were made. The images or other third party material in this article are included in the article's Creative Commons licence, unless indicated otherwise in a credit line to the material. If material is not included in the article's Creative Commons licence and your intended use is not permitted by statutory regulation or exceeds the permitted use, you will need to obtain permission directly from the copyright holder. To view a copy of this licence, visit http://creativecommons.org/licenses/by/4.0/.

\section{References}

Acheampong E, Macgregor CJ, Sloan S, Sayer J (2019) Deforestation is driven by agricultural expansion in Ghana's forest reserves. Sci African 5:e00146. https://doi.org/10.1016/j.sciaf.2019.e00146 
Alcamo J, Kok K, Busch G, Priess JA, Eickhout B et al (2006) Searching for the future of land: scenarios from the local to global scale. In: Lambin EF, Geist H (eds) Land-use and land-cover change local processes and global impacts. Springer, Berlin, p 19

Amisah S, Gyampoh A, Sarfo-Mensah P, Quagrainie K (2009) Livelihood trends in response to climate change in forest fringe communities of the Offin Basin in Ghana. J Appl Sci Environ Manag 13:5-15. https://doi.org/10.4314/jasem.v13i2.55294

Ankomah F, Kyereh B, Asante W, Ansong M (2019) Patterns of forest cover change and their association with forest management regimes of forest reserves in the high forest zone of Ghana. J Land Use Sci 14:242-257. https://doi.org/10.1080/1747423X.2019.1665116

Appiah M, Blay D, Damnyag L, Dwomoh FK, Pappinen A et al (2009) Dependence on forest resources and tropical deforestation in Ghana. Environ Dev Sustain 11:471-487. https://doi.org/10.1007/s10668007-9125-0

Arts B, Buizer M, Horlings L, Ingram V, van Oosten C et al (2017) Landscape approaches: a state-of-the-art review. Annu Rev Environ Resour 42:439-463. https://doi.org/10.1146/annurevenviron-102016-060932

Asante BO, Villano RA, Patrick IW, Battese GE (2018) Determinants of farm diversification in integrated crop - livestock farming systems in Ghana. Renew Agric Food Syst 33:131-149. https://doi.org/10. 1017/S1742170516000545

Asare R, Afari-Sefa V, Osei-Owusu Y, Pabi O (2014) Cocoa agroforestry for increasing forest connectivity in a fragmented landscape in Ghana. Agrofor Syst 88:1143-1156. https://doi.org/10.1007/ s10457-014-9688-3

van Asselen S, Verburg PH (2012) A land system representation for global assessments and land-use modeling. Glob Chang Biol 18: 3125-3148. https://doi.org/10.1111/j.1365-2486.2012.02759.x

Ayivor JS, Gordon C (2012) Impact of land use on river systems in Ghana. West Afr J App Ecol 20:83-95. https://www.ajol.info/ index.php/wajae/article/view/86344

Biggs R, Raudsepp-Hearne C, Atkinson-Palombo C, Bohensky E, Boyd $E$ et al (2007) Linking futures across scales: a dialog on multiscale scenarios. Ecol Soc 12(1):17. http://www.ecologyandsociety.org/ vol12/iss $1 / \operatorname{art} 17 /$

Boon E, Ahenkan A (2012) Assessing climate change impacts on ecosystem services and livelihoods in Ghana: case study of communities around Sui Forest Reserve. J Ecosyst Ecography 03:1-8. https:/ doi.org/10.4172/2157-7625.s3-001

Bunn C, Läderach P, Quaye A, Muilerman S, Noponen MRA et al (2019) Recommendation domains to scale out climate change adaptation in cocoa production in Ghana. Clim Serv 16:100123. https://doi.org/ 10.1016/j.cliser.2019.100123

Bürgi M, Ali P, Chowdhury A, Heinimann A, Hett C et al (2017) Integrated landscape approach: closing the gap between theory and application. Sustainability 9:1371. https://doi.org/10.3390/ su9081371

CBD (2011) The strategic plan for biodiversity 2011-2020 and the Aichi biodiversity targets. Montreal. https://www.cbdint/sp/. Accessed 11 April 2018

Creutzig F, Bren d'Amour C, Weddige U, Fuss S, Beringer T et al (2019) Assessing human and environmental pressures of global land-use change 2000-2010. Glob Sustain 2:1-17. https://doi.org/10.1017/ sus. 2018.15

Damnyag L, Saastamoinen O, Appiah M, Pappinen A (2012) Role of tenure insecurity in deforestation in Ghana's high forest zone. For Policy Econ 14:90-98. https://doi.org/10.1016/j.forpol.2011.08.006

Doelman JC, Stehfest E, Tabeau A, van Meijl H, Lassaletta L et al (2018) Exploring SSP land-use dynamics using the IMAGE model: regional and gridded scenarios of land-use change and land-based climate change mitigation. Glob Environ Chang 48:119-135. https://doi. org/10.1016/j.gloenvcha.2017.11.014
Ecker O (2018) Agricultural transformation and food and nutrition security in Ghana: does farm production diversity (still) matter for household dietary diversity? Food Policy 79:271-282. https://doi.org/10. 1016/j.foodpol.2018.08.002

Eitelberg DA, van Vliet J, Doelman JC, Stehfest E, Verburg PH (2016) Demand for biodiversity protection and carbon storage as drivers of global land change scenarios. Glob Environ Chang 40:101-111. https://doi.org/10.1016/j.gloenvcha.2016.06.014

ESA (2016) European Space Agency Climate Change Initiative LAND COVER - S2 prototype land cover 20m map of Africa 2016. http:// 2016africalandcover20m.esrin.esa.int/. Accessed 02 June 2018

FAO (2010) Managing forests for climate change. Rome. http://www. faoorg/3/i1960e/i1960e00pdf. Accessed 02 April 2019

FAO (2018) The state of the world's forests 2018 - forest pathways to sustainable development. Rome. http:/www.faoorg/documents/ card/en/c/19535EN/. Accessed 03 June 2018

FAOSTAT (2018) Crop statistics. Food and Agriculture Organization of the United Nations (FAO). http://www.fao.org/faostat/en/\#data/QC. Accessed 21 September 2017

Fedele G, Locatelli B, Djoudi H, Colloff MJ (2018) Reducing risks by transforming landscapes: cross-scale effects of land-use changes on ecosystem services. PLoS One 13:1-21. https://doi.org/10.1371/ journal.pone. 0195895

Foli S, Ros-Tonen MA, James R, Sunderland T (2018) Natural resource management schemes as entry points for integrated landscape approaches: evidence from Ghana and Burkina Faso. Environ Manag 62:82-97. https://doi.org/10.1007/s00267-017-0866-8

Forestry Commission (2010) Readiness preparation proposal Ghana. Accra. https://www.fcghana.org/assets/file/Programmes/. Accessed 05 May 2018

Forestry Commission (2016a) Ghana Forest plantation strategy: 20162040. Accra. https://fcghana.org/. Accessed 06 May 2018

Forestry Commission (2016b) Ghana REDD + strategy 2016-2035. Accra. https://fcghana.org/. Accessed 05 May 2018

Fortes P, Simoes S, Seixas J, van Regemorter D, Ferreira F (2013) Topdown and bottom-up modelling to support low- carbon scenarios: climate policy implications. Clim Pol 13:285-304. dx.doi.org. https://doi.org/10.1080/14693062.2013.768919

Friis C, Nielsen JØ, Otero I, Haberl H, Niewöhner J et al (2015) From teleconnection to telecoupling: taking stock of an emerging framework in land system science. J Land Use Sci 11:131-153. https:// doi.org/10.1080/1747423X.2015.1096423

Fuchs R, Prestele R, Verburg PH (2017) A global assessment of gross and net land change dynamics for current conditions and future scenarios. Earth Syst Dyn Discuss 9:441-458. https://doi.org/10.5194/esd2017-121

Ghana Statistical Service (2016) Population projections, 2010 and 2016. $\mathrm{https}: / /$ www.statsghana.gov.gh/nationalaccount_macros.php?Stats= MTA1NTY1NjgxLjUwNg==/webstats/s679n2sn87. Accessed 01 May 2018

Gockowski J, Sonwa D (2011) Cocoa intensification scenarios and their predicted impact on $\mathrm{CO} 2$ emissions, biodiversity conservation, and rural livelihoods in the Guinea rain forest of West Africa. Environ Manag 48:307-321. https://doi.org/10.1007/s00267-010-9602-3

Gollnow F, Göpel J, deBarros Viana Hissa L, Schaldach R, Lakes T (2018) Scenarios of land-use change in a deforestation corridor in the Brazilian Amazon: combining two scales of analysis. Reg Environ Chang 18:143-159. https://doi.org/10.1007/s10113-017$1129-1$

Government of Ghana (2011) Riparian buffer zone policy for managing freshwater bodies in Ghana. Accra. https://www.wrc-gh.org/ documents/acts-and-regulations/. Accessed 22 June 2018

Government of Ghana (2015) Ghana national spatial development framework (2015-2035)-executive summary. Accra. http://www. luspagovgh/files/NSDF\%20Final\%20Report\%20-\%20Vol\%20I\% 20Final\%20Edition_TACpdf. Accessed 28 Feb 2018 
Hackman KO, Gong P, Wang J (2017) New land-cover maps of Ghana for 2015 using Landsat 8 and three popular classifiers for biodiversity assessment. Int J Remote Sens 38:4008-4021. https://doi.org/ 10.1080/01431161.2017.1312619

Hansen C, Lund J, Treue T (2009) Neither fast, nor easy: the prospect of reduced emissions from deforestation and degradation (REDD) in Ghana. Int For Rev 11:439-455. https://doi.org/10.1505/ifor.11.4. 439

Heck V, Hoff H, Wirsenius S, Meyer C, Kreft H (2018) Land use options for staying within the planetary boundaries - synergies and tradeoffs between global and local sustainability goals. Glob Environ Chang 49:73-84. https://doi.org/10.1016/j.gloenvcha.2018.02.004

IUCN (2016) The economics of the Atewa Forest Range, Ghana. https:// ghana.arocha.org/wp-content/uploads/sites/15/2016/11/Atewabrochure-compleet-compressed1.pdf. Accessed 01 August 2018

IUCN (2018) Info forest landscape restoration, Ghana. https://infoflr.org/ countries/ghana. Accessed 10 August 2018

Kc S, Lutz W (2014) The human core of the shared socioeconomic pathways: population scenarios by age, sex and level of education for all countries to 2100. Glob Environ Chang 42:181-192. https:// doi.org/10.1016/j.gloenvcha.2014.06.004

Lambin EF, Meyfroidt P (2011) Global land use change, economic globalization, and the looming land scarcity. Proc Natl Acad Sci 108: 3465-3472. https://doi.org/10.1073/pnas.1100480108

Luskin MS, Lee JSH, Edwards DP, Gibson L, Potts MD (2018) Study context shapes recommendations of land-sparing and sharing; a quantitative review. Glob Food Sec 16:29-35. https://doi.org/10. 1016/j.gfs.2017.08.002

Malleson R, Asaha S, Egot M, Kshatriya M, Marshall E et al (2014) Nontimber forest products income from forest landscapes of Cameroon, Ghana and Nigeria - an incidental or integral contribution to sustaining rural livelihoods? Int For Rev 16:261-277. https://doi.org/ $10.1505 / 146554814812572449$

Mann C, Garcia-martin M, Raymond CM, Shaw BJ, Plieninger T (2018) The potential for integrated landscape management to fulfil Europe's commitments to the sustainable development goals. Landsc Urban Plan 177:75-82. https://doi.org/10.1016/j. landurbplan.2018.04.017

Meijer J, Giesen P, Shames S, Simons H, Kamstra J et al (2018) Towards a living landscape: using modelling and scenarios in the AtewaDensu landscape in Ghana: a case study on landscape strategies to achieve sustainable development goals. The Hague. https://www. pbl.nl/sites/default/files/downloads/PBL_2018_3280 LandscapeScenarioModelling case Ghana.pdf. Accessed $1 \overline{0}$ January 2019

Meyfroidt P, Lambin EF, Erb K-H, Hertel TW (2013) Globalization of land use: distant drivers of land change and geographic displacement of land use. Curr Opin Environ Sustain 5:438-444. https://doi.org/ 10.1016/j.cosust.2013.04.003

Milder JC, Hart AK, Dobie P, Minai J, Zaleski C (2014) Integrated landscape initiatives for African agriculture, development, and conservation: a region-wide assessment. World Dev 54:68-80. https:// doi.org/10.1016/j.worlddev.2013.07.006

Minang PA, Duguma LA, Bernard F, Mertz O, van Noordwijk M (2014) Prospects for agroforestry in REDD+ landscapes in Africa. Curr Opin Environ Sustain 6:78-82. https://doi.org/10.1016/j.cosust. 2013.10.015

National Development Planning Commission (2017) Black star rising. Long-term development plan of Ghana (2018-2057) outline. https://s3-us-west-2.amazonaws.com/new-ndpc-static1/CACHES/ PUBLICATIONS/2017/10/24/OUTLINE+-+LONG-TERM++ PLAN.pdf. Accessed 20 August 2018

National REDD+ Secretariat (2017) Ghana's national forest reference level. Accra. https://redd.unfccc.int/files/ghana_national reference level 01.01 2017 for unfccc-yaw kwakye.pdf. Accessed $\overline{02}$ June $\overline{2} 018$
Nilsson AE, Bay-Larsen I, Carlsen H, van Oort B, Bjørkan M et al (2017) Towards extended shared socioeconomic pathways: a combined participatory bottom-up and top-down methodology with results from the Barents region. Glob Environ Chang 45:124-132. https:// doi.org/10.1016/j.gloenvcha.2017.06.001

Nolte K, Chamberlain W, Giger M (2016) International land deals for agriculture fresh insights from the land matrix: analytical report II. Bern Open Publishing, Bern

O’Neill BC, Kriegler E, Ebi KL, Kemp-Benedict E, Riahi K et al (2017) The roads ahead: narratives for shared socioeconomic pathways describing world futures in the 21st century. Glob Environ Chang 42:169-180. https://doi.org/10.1016/j.gloenvcha.2015.01.004

Oduro KA, Mohren GMJ, Affum-Baffoe K, Kyereh B (2014) Trends in timber production systems in the high forest zone of Ghana. Int For Rev 16:289-300. https://doi.org/10.1505/146554814812572458

Okoffo ED, Denkyirah EK, Adu DT, Fosu-Mensah BY (2016) A doublehurdle model estimation of cocoa farmers' willingness to pay for crop insurance in Ghana. Springerplus 5(1):873. https://doi.org/10. 1186/s40064-016-2561-2

Palazzo A, Vervoort JM, Mason-D'Croz D, Rutting L, Havlik P et al (2016) Linking regional stakeholder scenarios and shared socioeconomic pathways: quantified West African food and climate futures in a global context. Glob Environ Chang 45:227-242. https://doi. org/10.1016/j.gloenvcha.2016.12.002

Popp A, Calvin K, Fujimori S, Havlik P, Humpenöder F et al (2017) Land-use futures in the shared socio-economic pathways. Glob Environ Chang 42:331-345. https://doi.org/10.1016/j.gloenvcha. 2016.10.002

Reed J, Van Vianen J, Deakin EL, Barlow J, Sunderland T (2016) Integrated landscape approaches to managing social and environmental issues in the tropics: learning from the past to guide the future. Glob Chang Biol 22:2540-2554. https://doi.org/10.1111/ gcb. 13284

Reed J, van Vianen J, Barlow J, Sunderland T (2017) Have integrated landscape approaches reconciled societal and environmental issues in the tropics? Land Use Policy 63:481-492. https://doi.org/10. 1016/j.landusepol.2017.02.021

Rizvi AR, Baig S, Barrow E, Kumar C (2015) Synergies between climate mitigation and adaptation in forest landscape restoration. Gland, Switzerland. https://portals.iucn.org/library/sites/library/files/ documents/2015-013.pdf. Accessed 02 November 2018

Satelligence (2017) Fraction of oil palm per $500 \times 500 \mathrm{~m}$ blocks, based on sentinel remote sensing data. Commissioned by the ILM project of the PBL Netherlands Environmental Assessment Agency

Sayer J, Sunderland T, Ghazoul J, Pfund J-L, Sheil D et al (2013) Ten principles for a landscape approach to reconciling agriculture, conservation, and other competing land uses. Proc Natl Acad Sci 110: 8349-8356. https://doi.org/10.1073/pnas.1210595110

Scherr SJ, Buck L, Willemen L, Milder JC (2014) Ecoagriculture: integrated landscape management for people, food, and nature. Encycl Agric Food Syst 3:1-17. https://doi.org/10.1016/B978-0-44452512-3.00029-2

Schroth G, Läderach P, Martinez-Valle AI, Bunn C, Jassogne L (2016) Vulnerability to climate change of cocoa in West Africa: patterns, opportunities and limits to adaptation. Sci Total Environ 556:231241. https://doi.org/10.1016/j.scitotenv.2016.03.024

Schueler V, Kuemmerle T, Schröder H (2011) Impacts of surface gold mining on land use systems in Western Ghana. Ambio 40:528-539. https://doi.org/10.1007/s13280-011-0141-9

Seppelt R, Lautenbach S, Volk M (2013) Identifying trade-offs between ecosystem services, land use, and biodiversity: a plea for combining scenario analysis and optimization on different spatial scales. Curr Opin Environ Sustain 5:458-463. https://doi.org/10.1016/j.cosust. 2013.05.002

Serna-Chavez HM, Schulp CJE, van Bodegom PM, Bouten W, Verburg PH et al (2014) A quantitative framework for assessing spatial flows 
of ecosystem services. Ecol Indic 39:24-33. https://doi.org/10.1016/ j.ecolind.2013.11.024

Thaxton M, Shames S, Scherr SJ (2017) Integrated landscape management: an approach to achieve equitable and participatory sustainable development. Global Land Outlook Working Paper Series 16. https://knowledge.unccd.int/publications/integrated-landscapemanagement-approach-achieve-equitable-and-participatory. Accessed 01 Jan 2019

Tieskens KF, Shaw BJ, Haer T, Schulp CJE, Verburg PH (2017) Cultural landscapes of the future: using agent-based modeling to discuss and develop the use and management of the cultural landscape of south west Devon. Landsc Ecol 32:2113-2132. https://doi.org/10.1007/ s10980-017-0502-2

Tsai YH, Stow DA, López-Carr D, Weeks JR, Clarke KC et al (2019) Monitoring forest cover change within different reserve types in southern Ghana. Environ Monit Assess 191. https://doi.org/10. 1007/s10661-019-7450-z

UN (2015) Transforming our world: the 2030 agenda for sustainable development. https://sustainabledevelopment.un.org/post2015/ transformingourworld/. Accessed 21 June 2018

UN (2019) World population prospects 2019: data booklet. https:// population.un.org/wpp/Publications/Files/WPP2019_DataBooklet. pdf. Accessed 10 June 2018

UNCCD (2012) Zero net land degradation: a sustainable development goal for Rio+20 to secure the contribution of our planet's land and soil to sustainable development, including food security and poverty eradication. Bonn, Germany. https://landportal.org/library/ resources/zero-net-land-degradation-sustainable-development-goalrio20-full-paper. Accessed 21 June 2018

UN-REDD (2018) Ghana's vision for REDD+: sustainable cocoa production and farmer livelihoods. https://www.un-redd.org/post/2018/ 12/10/ghana-s-vision-for-redd-sustainable-cocoa-production-andfarmer-livelihoods. Accessed 04 September 2018

van Notten P (2008) Scenario development: a typology of approaches. In: OECD (2006) Think Scenarios, Rethink Education. OECD Publishing, Paris, pp 68-87

Verburg PH, Overmars KP (2009) Combining top-down and bottom-up dynamics in land use modeling: exploring the future of abandoned farmlands in Europe with the Dyna-CLUE model. Landsc Ecol 24: 1167-1181. https://doi.org/10.1007/s10980-009-9355-7

Verburg PH, Eickhout B, van Meijl H (2008) A multi-scale, multi-model approach for analyzing the future dynamics of European land use. Ann Reg Sci 42:57-77. https://doi.org/10.1007/s00168-007-0136-4

Verburg PH, Erb K-H, Mertz O, Espindola G (2013) Land system science: between global challenges and local realities. Curr Opin Environ Sustain 5:433-437. https://doi.org/10.1016/j.cosust.2013. 08.001

Verburg PH, Alexander P, Evans T, Magliocca NR, Malek Z et al (2019) Beyond land cover change: towards a new generation of land use models. Curr Opin Environ Sustain 38:77-85. https://doi.org/10. 1016/j.cosust.2019.05.002

Verhagen W, van der Zanden EH, Strauch M, van Teeffelen AJA, Verburg PH (2018) Optimizing the allocation of agri-environment measures to navigate the trade-offs between ecosystem services, biodiversity and agricultural production. Environ Sci Pol 84:186196. https://doi.org/10.1016/j.envsci.2018.03.013

van Vliet J, Verburg PH (2018) A short presentation of CLUMondo. In: Olmedo Camacho MT, Paegelow M, Mas J-F, Escobar F (eds) Geomatic approaches for modeling land change scenarios. Springer International Publishing, Cham, pp 511-519

van Vuuren DP, Lucas PL, Hilderink H (2007) Downscaling drivers of global environmental change: enabling use of global SRES scenarios at the national and grid levels. Glob Environ Chang 17:114-130. https://doi.org/10.1016/j.gloenvcha.2006.04.004

van Vuuren DP, Smith SJ, Riahi K (2010) Downscaling socioeconomic and emissions scenarios for global environmental change research: a review. Wiley Interdiscip Rev Clim Chang 1:393-404. https://doi. org/10.1002/wcc. 50

Water Resources Commission (2012) National Integrated Water Resources Management (IWRM) plan. http://doc.wrc-gh.org/pdf/ National\%20IWRM\%20Plan.pdf. Accessed 11 June 2018

Wolff S, Schrammeijer EA, Schulp CJE, Verburg PH (2018) Meeting global land restoration and protection targets: what would the world look like in 2050? Glob Environ Chang 52:259-272. https://doi.org/ 10.1016/j.gloenvcha.2018.08.002

World Bank (2015) Ghana forest investment program - enhancing natural forest and agroforest landscape project. Washington D.C. http:// documents.worldbank.org/curated/en/494961557194531394/ Ghana-Forest-Investment-Program-and-Enhancing-Natural-Forestand-Agroforest-Landscapes-Project-Additional-Financing. Accessed 22 November 2018

Wu J (2013) Landscape sustainability science: ecosystem services and human well-being in changing landscapes. Landsc Ecol 28:9991023. https://doi.org/10.1007/s10980-013-9894-9

Zagaria C, Schulp CJE, Kizos T, Gounaridis D, Verburg PH (2017) Cultural landscapes and behavioral transformations: an agentbased model for the simulation and discussion of alternative landscape futures in East Lesvos, Greece. Land Use Policy 65:26-44. https://doi.org/10.1016/j.landusepol.2017.03.022

Zanzanaini C, Trần BT, Singh C, Hart A, Milder J et al (2017) Integrated landscape initiatives for agriculture, livelihoods and ecosystem conservation: an assessment of experiences from South and Southeast Asia. Landsc Urban Plan 165:11-21. https://doi.org/10.1016/j. landurbplan.2017.03

Publisher's note Springer Nature remains neutral with regard to jurisdictional claims in published maps and institutional affiliations. 